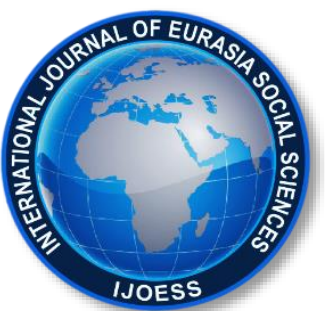

International Journal of Eurasia Social Sciences

Vol: 10, Issue: 37, pp. (692-708).

Research Article

Received: 02.01.2019 Accepted: 10.09.2019

\title{
THE EFFECT OF MANDATORY AUDIT FIRM ROTATION ON AUDIT QUALITY*
}

\author{
Neriman YALÇIN \\ Asst. Prof. PhD. Osmaniye Korkut Ata University, nerimanyalcin@gmail.com \\ ORCID: 0000-0002-2196-4779 \\ Alpaslan YAŞAR \\ Assoc. Prof. Adana Alparslan Türkeş Science and Technology University, ayasar@atu.edu.tr \\ ORCID: 0000-0002-7960-9665
}

\begin{abstract}
The discussions about whether the manner of application of mandatory rotation affects the audit quality still continue in developing countries and EU countries, notably the USA. Therefore, we investigate whether Mandatory Audit Firm Rotation (MROT) enhances audit quality in Turkey for the years 2010-2016. The findings show that companies audited by mandatorily rotated new auditors have less discretionary accruals and thus higher audit quality than those non-rotated audit firms (NROT). In addition, we find that the audit quality in companies that are subjected to the mandatory rotation is higher than the audit quality of the same companies one year ago under old audit firms. Thus, our findings support the idea that mandatory audit firm rotation enhances audit quality.
\end{abstract}

Keywords: Mandatory audit firm rotation, audit quality, discretionary accruals.

\footnotetext{
* This study was produced from the doctoral thesis titled "The effect of mandatory audit firm rotation on audit quality: An application in Istanbul Stock Exchange"
} 


\section{INTRODUCTION}

It is widely accepted in audit literature that the mandatory rotation application increases the audit quality by means of ensuring the auditor independence. However, the discussions on the manner of application of mandatory rotation in auditing continue in scholarly disputes and disputes at the regulatory authorities. This situation has caused countries to perform different applications relating to the mandatory rotation. Some of the countries adopt audit partner rotation or the mandatory audit firm rotation. On the other hand, some of the countries adopt both mandatory audit firm rotation and mandatory audit partner rotation. Accordingly, it is important to support by the empirical studies whether the mandatory rotation preferences of countries are effective on increasing the quality of audit.

There are positive or negative arguments which assume that mandatory rotation-related audit firm changes have negative or positive effects of the quality of the audit. It is mentioned in arguments which assume that mandatory rotation-related audit firm changes decrease the audit quality that the new auditor after the rotation cannot conduct an effective audit because of having less information about the customer; therefore, the audit quality is affected negatively (Johnson et al., 2002; Lennox, 2014; Kwon et al., 2014; Kim et al., 2015; Mohrmann, 2017). Since the new auditor is forced to rely on the estimations and declarations of the customer because of the lack of information on customers such as the operation of the business, accounting systems, and internal control structure; there might be seen a decrease in the audit quality in the first years of the contract after the mandatory rotation (Kwon et al., 2014: 173). The persons who support the mandatory rotation argue that the mandatory rotation provides a new fresh look and decreases the probability of development of personal relationships with the audit customer (Kim et al., 2015: 1090). Within this scope, there is an argument which assumes that introducing a time limit for the long relationship between the audit firm and client of the business will increase the auditor independence and quality of the audit (Chen et al., 2008: 416). Thus, it is pointed out that the new auditor can perform a high audit and reporting quality by remaining neutral and applying the professional skepticism in financial table auditing (Kim et al., 2015: 1092).

This paper that investigated the effect of the mandatory audit firm rotation on the quality of the audit was conducted in Turkey sample where 7 years of mandatory rotation is applied for audit firms and 5 years of mandatory rotation is applied the for auditors ${ }^{1}$. As is seen previous studies (i.e, Myers et al., 2003; Chi et al., 2009; Kim and Yi, 2009; Kim et al., 2015), we analyzed the effect of the mandatory audit firm rotation on the quality of audit by using the normal, positive (income increasing) and negative (income decreasing) values of discretionary accruals as the indicator of audit quality. First of all, we specified the mandatory audit firm sample for the years between 2010 and 2016 and compared it with two benchmark samples. Within this

\footnotetext{
${ }^{1} 2003$ year is specified as the year of start by the Capital Market Board's regulation which expresses that 'the companies cannot be audited by the same audit firm for more than 7 years'. Moreover, the period of 2003-2016 is considered to determine the companies that are subjected to the mandatory rotation. This consideration is based on the Public Oversight Institution's regulation which expresses that "the audits cannot be undertaken before 3 years relating to the companies in which 5 years of audit operation has been conducted in last seven years for the auditors and 7 years of audit operation has been conduted in last ten years for the audit organizations'.
} 
framework, the mandatory audit firm rotation was compared with the sample that has no rotation. We determined that the discretionary accruals of the companies that ride on the mandatory rotation are less (except the negative discretionary accruals) in comparison with the companies that have no rotation; accordingly, the audit quality is higher in the companies that ride on the mandatory rotation. Secondly, we compared the mandatory rotation sample with the previous form of the same sample before the mandatory rotation. The findings obtained show that the audit quality in companies that ride on the mandatory rotation is higher than the audit quality in the year before the mandatory rotation. So, our research findings support the argument that mandatory audit firm rotation increases the audit quality.

This study becomes different from previous studies in which the mandatory rotation was not virtually applied and the duration of tenure of the audit firm with the customer business was reviewed. Consequently, this research has contributed to the literature by means of directly analyzing the effect of the mandatory rotation firm rotation on the audit quality in the Turkey sample where the mandatory audit firm rotation is applied in.

Literature and hypothesis development was evaluated in the next chapters. We explained the sample selection, model and variables in Chapter 3 within the scope of the research methodology. Research findings can be seen in Chapter 5; the conclusion was shown in the last part of the article.

\section{LITERATURE REVIEW AND HYPOTHESIS DEVELOPMENT}

Literature has different arguments which assume that mandatory rotation may positively or negatively affect the quality of the audit quality or mandatory rotation has no effect on the audit quality. Following items are the most significant arguments of the persons who argue for the mandatory rotation; mandatory rotation affects the audit quality positively; mandatory rotation precludes the relationship between auditor and the client to turn into a relationship based on self-interest; mandatory rotation enables the auditor to strengthen his economic independence; the competition between the audit firms increases; being controlled by a new auditor brings a new fresh look; public perception about the auditor independence will increase (Mautz and Sharaf, 1961; Hoyle, 1978; Nagy, 2005; Raiborn et al., 2006; Lennox, 2007; Chen et al., 2008; Davis et al., 2009; Ewelt Knauer et al., 2013; Lennox, 2014; Burke and Lee, 2015). Moreover, following opinion comes to the forefront by the idea that mandatory rotation can increase the audit quality; placing a time limit for the long-dated relationship between the audit firm and client business will increase the auditor independence and the audit quality at the same time (Chen et al., 2008: 416). Thus, it is pointed out that the new auditor can perform a high audit and reporting quality by remaining neutral and applying the professional skepticism in auditing of financial statements (Kim et al., 2015: 1092). It is mentioned in arguments which assume that mandatory rotation-related audit firm changes decrease the quality of audit that the new auditor after the rotation cannot conduct an effective audit because of having less information about the client; therefore, the quality of the audit is affected negatively (Johnson et al., 2002; Lennox, 2014; Kwon et al., 2014; Kim et al., 2015). Professional skepticism of an auditor may lie fallow because of being seen the customer as a source of income 
due to the long-term inspection agreements; this circumstance may also decrease the audit quality (Carcello and Nagy, 2004: 57). The researchers who argue that there is a relation between the audit quality, audit period and the rotation pointed out that the probabilities of fradulent financial reporting and audit failure will increase as long as the auditor-customer relationship takes a long time. It is argued in investigations performed in terms of the audit quality measured via discretionary accruals that amounts of discretionary accruals are high in longdated auditor-customer relationships, and there is a decrease in the audit quality. Besides, the regulations that allow for an unlimited partnership process between the audit firms and the customers become a threat against the independence (ie; Casterella et al., 2002; Moore et al., 2006; Raiborn et al., 2006; Kaplan and Mauldin, 2008; Kim and Yii, 2009; Harris and Whisenant, 2012; Kim et al., 2015). The studies that were actualized within this framework show that the independence degree and the audit quality will decrease when the auditors recognize that their tenure expires.

It is mentioned as an opposite view against rotation application in the independent audit that frequency of financial reporting problems which emerge in the first years of auditor-customer relationship is higher in comparison with the advancing years. With reference to the expressions of practitioners of the audit activities, the audit quality is lower in the first years of the auditor-customer relationship; as making progress in familiarization process to the customer, the audit quality increases (i.e; Geiger and Raghunandan 2002; Johnson et al., 2002; Carcello and Nagy, 2004; Ghosh and Moon, 2005; Myers et al., 2003). The primary discussion towards the mandatory firm rotation is that the audit quality is lower in the first years of auditorcustomer relationship. Since the auditor is a stranger to the line of business, controls and accounting policies of the customer, it is suggested that the audit quality is low in the first year of the relationship. Moreover, a new auditor may not have a command of industrial error models. Previous studies found a significant relationship between the industry group, financial table error models and the fradulent financial reporting (Beasley et al., 1999: 2000). Accordingly, since a new auditor probably becomes less familiar with the industry of the customer, the probability of manipulatory reporting is higher. There are disadvantages against the argument which assumes that the rotation positively affects the market competition (Lennox, 2007: 95). Another critique of the persons who oppose mandatory rotation is the lame duck effect; the meaning of this effect is that as the year when the mandatory rotation will be performed, auditor's efforts during the auditing activities will decrease; namely, the auditor will not care two hoots (Ewelt-Knauer et al., 2013: 8). With reference to the survey results of GAO and interviews of public companies in Fortune 1000 list in 2011, the general run of the companies thinks that the costs of the mandatory rotation will exceed the benefits (Daniel and Booker, 2011: 79). As is seen above, the second most important cause of objection of anti-rotation is the costs (Davis et al., 2009; Ewelt-Knauer et al., 2013; Raibornet al., 2006). The incremental cost which emerges based upon the mandatory rotation during the planning and conducting the auditing activities was higher than the benefits sought (Johnson et al., 2002; Chi, 2005; Kwon et al., 2010; Cameran et al., 2015).

The previous studies (ie; Johnson et al., 2002; Myers et al., 2003; Carcello and Nagy, 2004; Mansi et al., 2004; Jackson et al., 2008; Davis et al., 2009) that investigate the relationship between audit quality and mandatory 
audit rotation were generally discussed based on the findings obtained through tenure of the audit firm and the auditing markets of the countries where the mandatory rotation application is not virtually applied in. Thus, commenting such research results in analogy to the mandatory audit firm rotation results creates a limit for the studies within the framework.

There is a limited number of studies that research the relationship between mandatory audit firm rotation and audit quality in the countries (for example; Italy, Korea and Spain) where the audit firm rotation is not virtually applied in. For example, Corbella et al. (2015) expressed that the mandatory audit firm rotation causes a significant decrease in the audit fees; however, there is no change in the audit quality. Kim et al. (2015) compared the companies that change mandatory audit firm in the first years of the inspection agreement in terms of the level of discretionary accruals and audit quality measured by going concern opinion (GCO) report about the continuity of financially distressed businesses. According to their research findings, mandatory audit firm rotation contributed to companies about giving going concern opinion on the continuity of financially distressed businesses, preventing the revenue growth behaviors and keeping the level of discretionary accruals low. Choi et al. (2017) conducted a study and concluded that mandatory audit firm rotation causes a decrease in audit quality in terms of the variables like the longness in auditing period, removing the auditor's background.

Different results can be seen in empirical studies about the relationship between mandatory audit firm rotation and audit quality. The hypothesis of this research that was conducted to measure the effect of the mandatory audit firm rotation on the audit quality in Turkey sample was established below;

\section{H1: Mandatory audit firm rotation effect on the audit quality.}

\section{RESEARCH DESIGN}

Univariate and multivariate analyses were performed in this research, which investigated the effect of the mandatory independent audit firm change on the audit quality by least squares regression method in the sample of manufacturing industry companies of İstanbul Stock Exchange in the years between 2010 and 2016. First of all, the sample of the research was classified as the companies which actualize mandatory audit firm rotation and the companies which do not actualize mandatory audit firm rotation. Secondly, the discretionary accruals of the companies in the sample were estimated by Kothari, Leone, and Wasley (2005) model. Afterward, a model was established with control variables by using the normal (signed), absolute, positive and negative values of discretionary accruals as the dependent variable. This model was subjected to the regression by least squares method.

\section{Sample Selection}

The manufacturing companies whose shares are publicly traded in the 2010-2016 period were selected as the sample in this research that reviewed the effect of the mandatory audit firm rotation on the effect of the audit 
quality. The data belong to the companies were obtained from the web pages of Public Disclosure Platform, Istanbul Stock Exchange and Public Oversight Institution. 1287 publicly-traded company-year data was determined. The companies which have extreme values and not continuity were excluded. In ordet to test the research hypothesis, the final sample of the research were classified as 95 MROT (mandatory audit firm rotation) and 653 NROT (non-rotation) data and consisted of a total of 748 company-year data.

\section{Model and Variables}

Discretionary accrual was used as the audit quality measure in this research that investigate the effect of the mandatory independent audit firm rotation on the independent audit quality. In order to test the research hypothesis, we compared the mandatory rotation sample (MROT) with two benchmarks as non-rotation (NROT) and before mandatory rotation (B_MROT). The discretionary accruals were computed using Kothari, Leone, and Wasley (2005) model (Model 1). Next, Model (2) was established by utilizing normal (signed), absolute, positive and negative values of discretionary accruals as the dependent variable; Model (2) was analyzed by least squares method.

\section{Estimating of Discretionary Accruals}

Discretionary accruals or abnormal accruals are the accruals emerge based on the discretionary power of the managers. These accruals are commonly used as an indirect indicator of the audit quality in the literature (Bartov et al., 2002; Myers et al., 2003; Nagy, 2005; Carey and Simmnet, 2006; Chen et al., 2008; Johnson et al., 2002; Chi et al., 2009; Kim et al., 2015). Low (high) level of discretionary accruals can be evaluated as an indicator of audit quality and high (low) earnings quality when the earnings management applications in terms of increasing or decreasing the profit come into question (ie; Myers et al., 2003; Chen et al., 2008; Chi et al., 2009).

Discretionary accruals are calculated with reference to the total accrual that is composed of the normal and abnormal accruals because of the calculation difficulties. Balance sheet and/or cash flow table approach is used to calculate the total accruals. Non-Discretionary accruals are estimated by the regression models (Jones Model, 1991; Dechow, Sloan and Sweeney-Corrected Jones Model, 1995; Benesih Model, 1997; Kothari Model, 2005) that are utilized in literature to estimate the non-discretionary part of the total accruals ${ }^{2}$. Next, the discretionary accruals are calculated by subtracting non-discretionary accruals from the total accruals.

In this research, discretionary accruals were computed by using below performance-matched model of Kothari, Leone, and Wasley (2005) because of reflecting the company performance better in the earnings management estimation based on Adjusted Jones Model (1995);

\footnotetext{
${ }^{2}$ Since Hribar and Collins (2002) argued that balance sheet approach potentially gives incorrect results in estimation of total accruals in comparison with cash flow table, this study preferred to use "income before extraordinary items - net operating cash flow".
} 


$$
D A_{i t}=T A_{i t} / A_{i t-1}-\left(\alpha_{i}\left[1 / A_{i t-1}\right]+\beta_{1 i}\left[\Delta R E V_{i t}-\Delta R E C_{i t} / A_{i t-1}\right]+\beta_{2 i}\left[P P E_{i t} / A_{i t-1}\right]+\beta_{3 i}\left[R O A_{i t-1}\right]\right)
$$

Model (1)

TA shows the total accruals; $A$ represents total assets; $\triangle R E V$ represents the change in net sales; $\triangle R E C$ shows the change in net trade receivable; PPE represents gross tangible assets; ROA shows the ratio of return on assets. As in previous studies, all the variables deflated by the total assets of the previous year to avoid the heteroscedasticity problem.

\section{Multivariate Test Model and Control Variables}

Normal (signed), absolute, positive (income increasing) and negative (income decreasing) values of discretionary accruals in Model 1 were used as the dependent variable in this study to test the effect of the mandatory audit firm rotation on the audit quality in Turkey. Within this framework, Model (2) below was established by putting discretionary accruals through regression via the control variables and the dummy variable that represents the rotation of the mandatory audit firm;

$$
\begin{aligned}
& D A_{i t}= \beta_{0}+\beta_{1} R O T+\beta_{2} L N_{A_{i t}}+\beta_{3} L E V_{i t}+\beta_{4} O C F_{i t}+\beta_{5} B I G 4_{i t}+\beta_{6} M B_{i t}+\beta_{7} G R O W+\beta_{8} L O S S_{i t}+ \\
& e_{i t} \\
& \text { Model (2) }
\end{aligned}
$$

Where;

DA = represents the discretionary accruals that are measured by normal (signed), absolute, positive and negative values obtained from Kothari Model (2005) regression

ROT = A dummy variable equal to 1 for the benchmark samples (NROT, B_MROT), otherwise 0

LN_A = Natural logarithm of the total assets

LEV $\quad=$ Total debt $/$ Total assets

OCF $=$ Cash flow/Total assets based upon the activity

BIG4 = It is 1 in case of being the audit firm one of the four powers; otherwise 0.

$\mathrm{MB}=$ Marketing value $/$ Book cost

GROW $=\Delta$ Net Sales

LOSS $=$ It is 1 if the loss was reported in the previous year; otherwise, 0 .

As is seen in the study of Chi et al., (2009), we estimated Model 2 for two comparison groups (MROT versus NROT; MROT versus B_MROT) by predicting ROT that is the fundamental purpose variable on. Within this scope; signed (normal), absolute, positive, and negative values of discretionary accruals were subjected to the regression via the ordinary least squares method (OLS) as one by one. Based on the previous works (ie; Myers et al., 2003; Chi et al., 2009), the control variables that are frequently used as the determinants of accruals were attached to the Model (2). Firstly, we included the size of an company variable (LN_A) in for controlling the effect of the size of an company on the accruals. Since the big companies are more consistent than the small companies, it is expected that the discretionary accruals remain at a lower level (Dechow and Dichev, 
2002). The second control variable that was used in the research is the financial leverage variable (LEV) that is utilized as the financial distress indicator (Jackson et al., 2008; Kim et al., 2015; Corbella et al., 2015). It is argued that the enterprises which have a high level of indebtedness apply earnings management that increases the discretionary accruals; accordingly, there will occur a positive effect of financial leverage on the discretionary accruals (Corbella et al., 2015; Cameran et al., 2016). On the other hand, the companies which experience financial distress are in the tendency to decrease their discretionary accruals (Becker et al., 1998; Francis and Wang, 2008). Thirdly, we included OCF variable to control the negative relationship between discretionary accruals and cash flows based on the transaction (Jackson et al., 2008; Chi et al., 2009; Cameran et al., 2016). Fourthly, we included the size of an audit firm variable (BIG4) to the model based on the results of the research (Becker et al., 1998; Myers et al., 2003; Francis and Yu, 2009) which assumes that 4 big audit firms will limit the profit management applications of their customers. The fifth variable in the model is the MB variable that shows the market value/book cost and has an increaser effect of positive discretionary accruals (Jackson et al., 2008; Yaşar, 2013). Besides, we used GROW variable as another control variable to control the positive effect of business growth on the accruals of the company (Myers et al., 2003; Carey and Simmnet, 2006; Jackson et al., 2008). Finally, we included LOSS variable that represents the loss belongs to the previous year to control the effect of the financial condition of the previous year on the accruals (Cameran et al., 2016).

\section{EMPIRICAL RESULTS}

The hypothesis of this research was tested by OLS Multiple Regression Model; the descriptive statistics of the research, univariate and multivariate analysis results presented in the following chapters.

\section{Descriptive Statistics}

The panels in Table 1 shows descriptive statistics for mandatory rotation sample (MROT), non-rotation sample (NROT) and before-rotation sample (B_MROT).

Table 1. Descriptive Statistics

\begin{tabular}{|c|c|c|c|c|c|c|}
\hline \multirow{2}{*}{$\begin{array}{l}\text { PANEL A: } \\
\text { Variables }\end{array}$} & \multicolumn{3}{|c|}{ Mandatory Rotation Sample (MROT, N= 95) } & \multirow[b]{2}{*}{ Std. Deviation } & \multirow[b]{2}{*}{ Min. } & \multirow[b]{2}{*}{ Max. } \\
\hline & $\mathrm{N}$ & Mean & Median & & & \\
\hline DA & 95 & -0.0157 & -0.0248 & 0.0540 & -0.1222 & 0.1458 \\
\hline$|\mathrm{DA}|$ & 95 & 0.0455 & 0.0402 & 0.0327 & 0.0003 & 0.1458 \\
\hline $\mathrm{DA}+$ & 37 & 0.0383 & 0.0246 & 0.0382 & 0.0003 & 0.1458 \\
\hline $\mathrm{DA}^{-}$ & 58 & -0.0502 & -0.0463 & 0.0281 & -0.1222 & -0.0020 \\
\hline LN_A & 95 & 19.5392 & 19.5613 & 1.5709 & 14.0667 & 23.3290 \\
\hline LEV & 95 & 0.4982 & 0.4407 & 0.3692 & 0.0437 & 2.9908 \\
\hline OCF & 95 & 0.4807 & 0.0511 & 0.1504 & -1.0229 & 0.3857 \\
\hline BIG4 & 95 & 0.6500 & 1.0000 & 0.4790 & 0.0000 & 1.0000 \\
\hline $\mathrm{MB}$ & 95 & 3.9272 & 1.4600 & 12.6767 & -12.0100 & 103.8900 \\
\hline GROW & 95 & 0.1441 & 0.1556 & 0.2093 & -1.0000 & 0.7700 \\
\hline LOSS & 95 & 0.3400 & 0.0000 & 0.4750 & 0.0000 & 1.0000 \\
\hline
\end{tabular}


Table 1 (continued)

\begin{tabular}{|c|c|c|c|c|c|c|}
\hline \multirow{2}{*}{$\begin{array}{l}\text { PANEL B: } \\
\text { Variables }\end{array}$} & \multicolumn{6}{|c|}{ Non-Rotation Sample (NROT, N=653) } \\
\hline & $\mathrm{N}$ & Mean & Median & Std. Deviation & Min. & Max. \\
\hline DA & 653 & 0.0023 & -0.0022 & 0.0908 & -0.4910 & 0.8327 \\
\hline$|\mathrm{DA}|$ & 653 & 0.0553 & 0.0341 & 0.0720 & 0.0001 & 0.8327 \\
\hline DA+ & 309 & 0.0609 & 0.0327 & 0.0855 & 0.0001 & 0.8327 \\
\hline $\mathrm{DA}^{-}$ & 344 & -0.0503 & -0.0347 & 0.0570 & -0.4910 & -0.0002 \\
\hline LN_A & 653 & 19.6975 & 19.5413 & 1.5748 & 15.0585 & 24.1643 \\
\hline LEV & 653 & 0.5086 & 0.4543 & 0.5236 & 0.0364 & 8.6743 \\
\hline OCF & 653 & 0.0672 & 0.0572 & 0.2515 & -1.4858 & 5.4352 \\
\hline BIG4 & 653 & 0.6600 & 1.0000 & 0.4740 & 0.0000 & 1.0000 \\
\hline $\mathrm{MB}$ & 653 & 2.0321 & 1.3900 & 4.0244 & -22.0000 & 79.4100 \\
\hline GROW & 653 & 0.3259 & 0.1004 & 5.0488 & -0.9800 & 128.8900 \\
\hline LOSS & 653 & 0.2400 & 0.0000 & 0.4300 & 0.0000 & 1.0000 \\
\hline PANEL C: & \multicolumn{6}{|c|}{ Mandatory Rotation Sample Before One Year (B_MROT, N= 95) } \\
\hline Variables & $\mathrm{N}$ & Mean & Median & Std. Deviation & Min. & Max. \\
\hline DA & 95 & -0.0015 & -0.0059 & 0.1088 & -0.2471 & 0.3939 \\
\hline$|\mathrm{DA}|$ & 95 & 0.0789 & 0.0525 & 0.0745 & 0.0019 & 0.3939 \\
\hline $\mathrm{DA}+$ & 45 & 0.0816 & 0.0483 & 0.0854 & 0.0019 & 0.3939 \\
\hline $\mathrm{DA}^{-}$ & 50 & -0.0764 & -0.0561 & 0.0639 & -0.2471 & -0.0030 \\
\hline LN_A & 95 & 19.5018 & 19.4953 & 1.4844 & 15.9615 & 23.1347 \\
\hline LEV & 95 & 0.5016 & 0.4077 & 0.5593 & 0.0785 & 5.2625 \\
\hline OCF & 95 & 0.1188 & 0.0625 & 0.5648 & -0.3872 & 5.4352 \\
\hline BIG4 & 95 & 0.5900 & 1.0000 & 0.4950 & 0.0000 & 1.0000 \\
\hline MB & 95 & 1.8942 & 1.2300 & 5.3775 & -13.3400 & 47.9000 \\
\hline GROW & 95 & 0.0051 & -0.0119 & 0.2993 & -0.7200 & 1.8600 \\
\hline LOSS & 95 & 0.2600 & 0.0000 & 0.4430 & 0.0000 & 1.0000 \\
\hline
\end{tabular}

It is seen when the panels are aligned based on (|DA|) means of discretionary accruals that MROT sample in Panel (A) has the lowest absolute discretionary accrual $(0,0455))$. The LEV variable was actualized as $50 \%$ in sample groups in each of the three panels. Moreover, as is seen in Table, more than $60 \%$ of the companies in all the sample groups are controlled by the big fours.

\section{Univariate Analysis}

Parametric t-test results of the mean difference of discretionary accruals for mandatory rotation (MROT), nonrotation (NROT) and before the mandatory rotation (B_MROT) presented in Table 2.

Table 2. Univariate Analysis Results

\begin{tabular}{llcccc}
\hline Panel A: & \multicolumn{6}{l}{ Mandatory Rotation- Non-Rotation Results $\mathbf{( N = 7 4 8 )}$} & & \\
\hline Variables & Rotasyon Status & $\mathrm{N}$ & Mean & t-statistic & -value \\
DA & MROT & 95 & -0.0157 & $-1.886^{*}$ & 0.060 \\
& NROT & 653 & 0.0908 & & \\
$|\mathrm{DA}|$ & MROT & 95 & 0.0455 & -1.306 & 0.192 \\
& NROT & 653 & 0.0553 & & \\
DA+ & MROT & 37 & 0.0383 & -1.589 & 0.113 \\
& NROT & 309 & 0.0609 & & \\
DA $^{-}$ & MROT & 58 & -0.0501 & 0.022 & 0.983 \\
& NROT & 344 & -0.0503 & & \\
\hline
\end{tabular}


Table 2 (continued)

\begin{tabular}{|c|c|c|c|c|c|}
\hline \multirow{2}{*}{$\begin{array}{l}\text { Panel B: } \\
\text { Variables }\end{array}$} & \multicolumn{5}{|c|}{ Mandatory Rotation - One Year Before Mandatory Rotation ( $\mathrm{N}=190)$} \\
\hline & Rotasyon Status & $\mathrm{N}$ & Mean & t-statistic & $p$-value \\
\hline \multirow[t]{2}{*}{ DA } & MROT & 95 & -0.0157 & -1.136 & 0.257 \\
\hline & B_MROT & 95 & -0.0015 & & \\
\hline \multirow[t]{2}{*}{$|D A|$} & MROT & 95 & 0.0455 & $-3.991^{* * *}$ & 0.000 \\
\hline & B_MROT & 95 & 0.0788 & & \\
\hline \multirow[t]{2}{*}{$\mathrm{DA}+$} & MROT & 37 & 0.0383 & $-2.855^{* *}$ & 0.005 \\
\hline & B_MROT & 45 & 0.0816 & & \\
\hline \multirow[t]{2}{*}{$\mathrm{DA}^{-}$} & MROT & 58 & -0.0501 & $2.827^{* *}$ & 0.006 \\
\hline & B_MROT & 50 & -0.0763 & & \\
\hline
\end{tabular}

$*, * *, * * * \mathrm{p}<.10, .05, .01$, respectively.

As seen on Table 2; the results of the univariate analysis ( $t$ test) performed without taking into account the variables that are thought to affect audit quality due to discretionary accruals were checked and it was observed that mandatory audit firm rotation had a positive effect on independent audit quality measured by discretionary accruals.

\section{Multivariate Regression Analysis}

In addition to the univariate analysis, we examined the effect of mandatory audit firm rotation on the audit quality by using Model 2 in which the effects of other variables that can affect the discretionary accruals are controlled and presented in the panels of Table 3. The regression results that were obtained by using the normal (signed) values of discretionary accruals as dependent variable presented in Panel A of Table 3.

Table 3. The Effect of Mandatory Audit Firm Rotation on Discretionary Accruals

\begin{tabular}{|c|c|c|c|}
\hline \multicolumn{4}{|c|}{ Panel A: Regression Results with Normal (signed) Discretionary Accruals (DA) } \\
\hline \multirow[t]{2}{*}{ Variables } & Expected sign & (I) & (II) \\
\hline & & MROT / NROT & MROT/B_MROT \\
\hline \multirow[t]{2}{*}{ Constant } & ? & -0.006 & -0.086 \\
\hline & & $(-0.176)$ & $(-1.290)$ \\
\hline \multirow[t]{2}{*}{ ROT } & $?$ & $-0.018 * *$ & $-0.025 * *$ \\
\hline & & $(-2.717)$ & $-(2.633)$ \\
\hline \multirow[t]{2}{*}{ LN_A } & $?$ & 0.002 & $0.006 *$ \\
\hline & & $(1.313)$ & $(1.661)$ \\
\hline \multirow[t]{2}{*}{ LEV } & $?$ & -0.015 & 0.014 \\
\hline & & $(-1.533)$ & $(0.792)$ \\
\hline \multirow[t]{2}{*}{ OCF } & - & $-0.519 * * *$ & $-0.555 * * *$ \\
\hline & & $(-26.547)$ & $(-12.888)$ \\
\hline \multirow[t]{2}{*}{ BIG4 } & $?$ & -0.001 & 0.004 \\
\hline & & $(-0.244)$ & (0.419) \\
\hline \multirow[t]{2}{*}{$\mathrm{MB}$} & + & $0.002 *$ & 0.002 \\
\hline & & (1.749) & $(1.068)$ \\
\hline \multirow[t]{2}{*}{ GROW } & $?$ & $0.045^{* * *}$ & $0.042 * *$ \\
\hline & & (6.080) & $(2.231)$ \\
\hline \multirow[t]{2}{*}{ LOSS } & + & $-0.018 * *$ & -0.015 \\
\hline & & $(-3.063)$ & $(-1.273)$ \\
\hline Observations (N) & & 748 & 190 \\
\hline $\mathrm{R}^{2}$ & & 0.517 & 0.523 \\
\hline Adjusted $\mathrm{R}^{2}$ & & 0.512 & 0.501 \\
\hline
\end{tabular}


We find that ROT coefficient on MROT versus NROT in Panel A is significant at 0.05 significance level $(-0.018, t=$ -2.717). This result show that discretionary accruals of the companies which are subjected to the mandatory audit firm rotation are lower (audit quality is higher) in comparison with the countries which are not subjected to the same rotation. Secondly, we find that ROT coefficient on MROT versus B_MROT column is significant at 0.05 significance level $(-0,025, t=-2,633)$. This result proves us the audit quality with the new auditor is higher in companies that are subjected to the mandatory audit firm rotation in comparison with the audit quality of the same companies in previous audit firm in the previous year.

On Panel B in Table 3, we reported the findings which obtained using the absolute value (|DA|) of discretionary accruals as the dependent variable.

Table 3 (Continued)

\begin{tabular}{|c|c|c|c|}
\hline \multicolumn{4}{|c|}{ Panel B: Regression Results with Absolute Discretionary Accruals (|DA|) } \\
\hline \multirow[t]{2}{*}{ Variables } & Expected sign & (I) & (II) \\
\hline & & MROT / NROT & MROT/B_MROT \\
\hline \multirow[t]{2}{*}{ Constant } & $?$ & $0.186 * * *$ & 0.067 \\
\hline & & $(5.665)$ & $(1.076)$ \\
\hline \multirow[t]{2}{*}{ ROT } & $?$ & $-0.012^{*}$ & $-0.035 * * *$ \\
\hline & & $(-1.809)$ & $(-3.948)$ \\
\hline \multirow[t]{2}{*}{ LN_A } & $?$ & $-0.007 * * *$ & 0.001 \\
\hline & & $(-4.144)$ & (0.186) \\
\hline \multirow[t]{2}{*}{ LEV } & ? & 0.007 & 0.023 \\
\hline & & $(0.701)$ & (1.343) \\
\hline \multirow{2}{*}{ OCF } & - & $-0,052 * *$ & 0.005 \\
\hline & & $(-2.615)$ & (0.129) \\
\hline \multirow[t]{2}{*}{ BIG4 } & $?$ & -0.005 & -0.012 \\
\hline & & $(-0.851)$ & $(-1.219)$ \\
\hline \multirow[t]{2}{*}{$\mathrm{MB}$} & + & 0.001 & -0.001 \\
\hline & & (1.192) & $(-0.512)$ \\
\hline \multirow[t]{2}{*}{ GROW } & $?$ & $0.079 * * *$ & 0.020 \\
\hline & & (10.485) & (1.189) \\
\hline \multirow[t]{2}{*}{ LOSS } & + & -0.003 & -0.007 \\
\hline & & $(-0.510)$ & $(-0.683)$ \\
\hline \multicolumn{2}{|l|}{ Observations (N) } & 748 & 190 \\
\hline \multicolumn{2}{|l|}{$R^{2}$} & 0.181 & 0.108 \\
\hline \multicolumn{2}{|l|}{ Adjusted $\mathrm{R}^{2}$} & 0.172 & 0.069 \\
\hline
\end{tabular}

We find that the coefficient on ROT is significant $(-0.012, t=-1.809)$ in MROT versus NROT column. This result shows that the absolute value of discretionary accruals of the companies which are subjected to the mandatory audit firm rotation is lower (audit quality is higher) in comparison with the companies which are not subjected to the same rotation. In addition, we find that ROT coefficient on MROT versus B_MROT column is significant at 0.01 significance level $(-0.035, t=-3.948)$. This result proves us the audit quality with the new auditor is higher in companies that are subjected to the mandatory audit firm rotation in comparison with the audit quality of the same companies one year earlier in previous audit firm.

As in previous studies (Myers et al., 2003; Chi et al., 2009), we estimated Model 2 one by one for positive and 
negative discretionary accruals. We reported the findings on C and D panels of Table 3 .

First, ROT coefficient on MROT versus NROT column in Panel C is negatively significant at 0.05 significance level $(-0.024, t=-2.270)$. We can say with reference to this result that new auditors after the mandatory rotation limit the income increasing discretionary accruals in comparison with the companies without rotation. Secondly, ROT coefficient on MROT versus B_MROT column is significant at 0.01 significance level $(-0.045, t=-3.512)$. This result suggesting that new auditors after the mandatory rotation limit the positive (income increasing) discretionary accruals more in comparison with the old auditors in the previous year.

Table 3 (Continued)

\begin{tabular}{|c|c|c|c|}
\hline \multicolumn{4}{|c|}{ Panel C: Regression Results with Absolute Discretionary Accruals (DA ${ }^{+}$) } \\
\hline \multirow[t]{2}{*}{ Variables } & Expected sign & (I) & (II) \\
\hline & & MROT / NROT & MROT/B_MROT \\
\hline \multirow[t]{2}{*}{ Constant } & ? & 0.085 & $-0,093$ \\
\hline & & $(1.651)$ & $(-0,884)$ \\
\hline \multirow[t]{2}{*}{ ROT } & ? & $-0.024^{* *}$ & $-0,045 * * *$ \\
\hline & & $(-2.270)$ & $(-3,512)$ \\
\hline \multirow[t]{2}{*}{ LN_A } & ? & -0.001 & 0,009 \\
\hline & & $(-0.552)$ & $(1,608)$ \\
\hline \multirow[t]{2}{*}{ LEV } & ? & -0.015 & 0,025 \\
\hline & & $(-1.011)$ & $(0,969)$ \\
\hline \multirow[t]{2}{*}{ OCF } & - & $-0.452 * * *$ & $-0,509 * * *$ \\
\hline & & $(-13.336)$ & $(-6,159)$ \\
\hline \multirow[t]{2}{*}{ BIG4 } & $?$ & -0.006 & $-0,008$ \\
\hline & & $(-0.770)$ & $-0,576$ \\
\hline \multirow[t]{2}{*}{ MB } & + & 0.001 & $-0,001$ \\
\hline & & $(1.044)$ & $(-0,397)$ \\
\hline \multirow[t]{2}{*}{ GROW } & $?$ & $0.065^{* * *}$ & 0,023 \\
\hline & & (7.241) & (0973) \\
\hline \multirow[t]{2}{*}{ LOSS } & + & -0.008 & $-0,017$ \\
\hline & & $(-0.984)$ & $(-1,068)$ \\
\hline Observations (N) & & 346 & 82 \\
\hline $\mathrm{R}^{2}$ & & 0.471 & 0,456 \\
\hline Adjusted $\mathrm{R}^{2}$ & & 0.458 & 0,397 \\
\hline
\end{tabular}

ROT coefficient on MROT versus NROT column was found as statistically insignificant for the income increasing discretionary accruals on Panel $\mathrm{D}$ in Table $3(-0.003, \mathrm{t}=-0.472)$.

Table 3 (Continued)

\begin{tabular}{|c|c|c|c|}
\hline \multicolumn{4}{|c|}{ Panel D: Regression Results with Absolute Discretionary Accruals (DA') } \\
\hline \multirow[t]{2}{*}{ Variables } & Expected sign & (I) & (II) \\
\hline & & MROT / NROT & MROT/B_MROT \\
\hline \multirow[t]{2}{*}{ Constant } & $?$ & $-0.122 * * *$ & -0.094 \\
\hline & & $(-4.094)$ & $(-1.635)$ \\
\hline \multirow[t]{2}{*}{ ROT } & $?$ & -0.003 & 0.014 \\
\hline & & -0.472 & $(1.556)$ \\
\hline \multirow[t]{2}{*}{ LN_A } & $?$ & $0.006 * * *$ & 0.002 \\
\hline & & (3.841) & $(0.763)$ \\
\hline \multirow[t]{2}{*}{ LEV } & $?$ & $-0.024 * *$ & -0.016 \\
\hline & & $(-2.400)$ & $(-0.865)$ \\
\hline \multirow[t]{2}{*}{ OCF } & - & $-0.267 * * *$ & $-0.243 * * *$ \\
\hline & & $(-11.343)$ & $(-5.242)$ \\
\hline
\end{tabular}




\begin{tabular}{llll}
\hline BIG4 & $?$ & 0.005 & 0.014 \\
& & $(0.946)$ & $(1.385)$ \\
MB & + & 0.000 & 0.001 \\
& & $(0.184)$ & $(0.484)$ \\
GROW & $?$ & $-0.051 * * *$ & 0.016 \\
LOSS & & -4.939 & $(0.882)$ \\
& + & -0.006 & 0.007 \\
Observations (N) & & $(-0.993)$ & $(0.610)$ \\
R $^{2}$ & & 402 & 108 \\
Adjusted R & & 0.299 \\
\hline
\end{tabular}

$*, * *, * * * p<.10, .05, .01$, respectively.

In sum, there is a difference between the sample with mandatory audit firm rotation, the companies without rotation and the sample before the mandatory rotation sample in terms of normal, absolute and positive values of discretionary accruals (except the negative values). Mandatory audit firm rotation has a restrictive effect on the discretionary accruals at two comparison levels (MROT/ NROT, MROT/ B_MROT) except the negative discretionary accruals in the first year after the mandatory audit firm rotation. In other words, the audit quality of the mandatory rotation sample was higher than the audit quality of the sample without rotation and the audit quality of the previous year in the same companies. While this result confirms some previous research results (ie; Nagy, 2005; Kim and Yii, 2009; Harris and Whisenant, 2012; Kim et al., 2015), it does not confirm others (ie; Myers et al., 2003; Chi et al., 2009; Cameran et al., 2015; Mohrmann, 2017).

\section{CONCLUSION}

In this research, the effect of the mandatory audit firm rotation on the audit quality was analyzed by using discretionary accruals as the indicator of audit quality in Turkey sample where the mandatory audit firm rotation has been applied in as of 2010.

The effect of mandatory audit firm rotation on the independent audit quality was reviewed by using normal, absolute, positive (income increasing) and negative (income decreasing) values of the discretionary accruals as an indicator of the audit quality. Within this framework, first of all, discretionary accruals of the mandatory audit firm rotation sample was compared with the sample without rotation. The findings obtained show us the discretionary accruals (except negative discretionary accruals) of companies that are subjected to the mandatory rotation is lower in comparison with the companies without rotation; accordingly, the audit quality increases. Secondly, discretionary accruals of mandatory rotation sample were compared with the discretionary accruals of the same companies in the previous year. The result suggest that the audit quality in companies that are subjected to the mandatory rotation is higher than the audit quality in the year before the mandatory rotation. Thus, our research findings confirm that the mandatory audit firm rotation increases the audit quality. While this result consistent with some of the research results (ie; Kim and Yii, 2009; Harris and Whisenant, 2012; Kim et al., 2015,), this result does not consistent with other research results (ie; Myers et al., 2003; Chi et al., 2009; Cameran et al., 2015; Mohrmann, 2017). 
This study is a research that was conducted in a developing country sample in which the mandatory audit firm rotation is virtually applied. We also considered the normal (signed), absolute, positive and negative values of discretionary accruals as the indicator of the audit quality. This research contributes to the literature due to these two reasons above.

As in every research, this study has some limitations. One of the limitations of our study is being used the discretionary accruals as the indicator of the audit quality; however, discretionary accruals are generally used as the financial reporting quality. Since Lennox (2014:99) mentioned that the earnings quality is a function of both the reporting preferences of the directors and the audit quality, it is a question of debate that whether the discretionary accruals are proper as the indicator of the quality of the audit. Moreover, Chi et al., (2009:385) pointed out that accrual-based proxies are the noisy measurements. Therefore, it is possible to be used the alternative indicators of audit quality such as quality of transparency reporting, going concern audit opinions (audit opinion reporting including uncertainty relating to the business continuity), and audit fees in the next studies. In addition to all these, there may occur different results about the relationship between mandatory rotation and the audit quality levels that will be measured in a sample that covers other sectors except the manufacturing industry.

\section{REFERENCES}

Bartov, E., Givolyb, D. and Haync, C. (2002). "The Rewards to Meeting or Beating Earnings Expectations", Journal of Accounting and Economics, 33 (1), 173-204.

Beasley, M. S., Carcello, J. V. and Hermanson, D. R. (1999). Fraudulent Financial Reporting 1987-1997: An Analysis of U.S. Public Companies. Committee of Sponsoring Organizations of the Treadway Commission. Jersey City, NJ: AICPA.

Becker, C. L., Defond, M.L., Jiambalvo, J. and Subramanyan, K.R. (1998). "The Effect of Audit Quality on Earnings Management", Contemporary Accounting Research, 15, 1-24.

Burke, J.A. and Lee, H. (2015). "Protecting the Public Interest through Mandatory Auditor Firm Rotation: A Controversial Issue," in Cheryl R. Lehman (ed.), Sustainability and Governance (Advances in Public Interest Accounting, Volume 18) Emerald Group Publishing Limited, 1 - 55.

Cameran, M., Francis, J.R., Marra, A. and Pettinicchio, A. (2015). "Are There Adverse Consequences of Mandatory Auditor Rotation? Evidence from the Italian Experience," Auditing: A Journal of Practice \& Theory American Accounting Association, 34(1), 1-24.

Cameran, M., Prencıpe, A. and Trombetta M. (2016). "Mandatory Audit Firm Rotation and Audit Quality," European Accounting Review, 25(1), 35-58.

Carcello, J. V., and Nagy, A. L. (2004). “Audit Firm Tenure and Fraudulent Financial Reporting”, Auditing: A Journal of Practice \& Theory, 23(2), 55-69. 
Carey, P. and Simnett, R. (2006). “Audit Partner Tenure and Audit Quality”, The Accounting Review, 81(3), 653676.

Casterella J, Knechel, W.R. and Walker, P.L (2002). "The Relationships of Audit Failures and Auditor Tenure", Working Paper, University of Florida.

Chen, C., Lin, C. and Lin, Y. (2008). “Audit Partner Tenure, Audit Firm Tenure and Discretionary Accruals: Does Long-Term Auditor Tenure Impair Earnings Quality?", Contemporary Accounting Research, 25(2), 415 445.

Chi, W. and Huang, H. (2005). "Discretionary Accruals, Audit Firm Tenure and Audit Partner Tenure: Empirical Evidence from Taiwan", Journal of Contemporary Accounting and Economics, 1(1), 1-65.

Chi, W., Huang H., Liao Y. and Xie H. (2009). "Mandatory Audit Partner Rotation, Audit Quality, and Market Perception: Evidence from Taiwan", Contemporary Accounting Research, 26(2), 359-91.

Choi, J., Lim, H. and Mali, D. (2017). "Mandatory Audıt Firm Rotation And Big4 Effect On Audit Qualıty: Evidence From South Korea", Asian Academy of Management Journal of Accounting \& Finance, 13(1), 1-40.

Corbellaa, F., C., Gottib, G. and M., Astrolia S.A. (2015). “Audit Firm Rotation, Audit Fees and Audit Quality: The Experience of Italian Public Companies", Journal of International Accounting, Auditing and Taxation, 25(1), 46-66.

Daniels, B. W., and Booker, Q. (2011). "The Effects of Audit Firm Rotation on Perceived Auditor Independence and Audit Quality", Research in Accounting Regulation, 23(1), 78-82.

Davis, L. R., Soo, B. S. and Trompeter, G. M. (2009). "Auditor Tenure and the Ability to Meet or Beat Earnings Forecasts", Contemporary Accounting Research, 26(2), 517-548.

Dechow, P., and Dichev, I. (2002). "The Quality of Accruals and Earnings: The Role of Accrual Estimation Errors", The Accounting Review, 77(1), 35-59.

Ewelt- Knauer, C., Gold, A. and Pott, C. (2013). “Mandatory Audit Firm Rotation: A Review of Stakeholder Perspectives and Prior Research", Accounting in Europe, 10(1), 27-41.

Francis, J. And Wang D. (2008). "The Joint Effect of Investor Protection and Big 4 Audits on Earnings Quality around the World", Contemporary Accounting Research, 25(1), 1-39.

Francis J.R. and Yu, M. (2009). "Big 4 Office Size and Audit Quality", The Accounting Review, 84(5), 1521-1552.

Geiger, M.A., Raghunandan, K. and Rama, D.V. (2002). “Auditor Tenure and Audit Reporting Failures”, Auditing: A Journal of Practise \& Theory, 21(1), 67-74.

Ghosh, A. and Moon, D.C. (2005). "Audit Tenure and Perceptions of Audit Quality", The Accounting Review, 80(2), 585- 612 .

Harris, K. and Whisenant, S. (2012). "Mandatory Audit Rotation: An International Investigation", Working paper, Houston TX: Bauer College of Business, The University of Houston.

Hoyle, J. (1978). "Mandatory Auditor Rotation: The Arguments and Alternative", Journal of Accountancy, 145(5), 69- 78.

Hribar D. and Collins, W. (2002). "Errors in Estimating Accruals: Implications for Empirical Research", Journal of Accounting Research, 40(1), 105-134. 
Jackson, A.B., Moldrich, M. and Roebuck, P. (2008). "Mandatory Audit Firm Rotation and Audit Quality", Managerial Auditing Journal, 23(5), 420-437.

Johnson, V.E., Khurana, I.K. and Reynolds, J.K. (2002). "Audit-Firm Tenure and the Quality of Financial Reports", Contemporary Accounting Research, 19(4), 637-60.

Kaplan, S. E., and Mauldin, E. G. (2008). “Auditor Rotation and the Appearance of Independence: Evidence From Non-Professional Investors", Journal of Accounting \& Public Policy, 27(2), 177-192.

Kim, J.B. and Yii C.H. (2009). “Does Auditor Designation by the Regulatory Authority Improve Audit Quality? Evidence from Korea", Journal of Accounting and Public Policy, 28(3), 207-230.

Kim, H., Lee, H. and Lee J.E. (2015). “Mandatory Audit Firm Rotation And Audit Quality”, The Journal of Applied Business Research, 31(3), 1089-2008.

Kothari, S. P., Leone, A. J. and Wasley, C. E. (2005). "Performance matched discretionary accrual measures", Journal of Accounting and Economics, 39(1), 163-197.

Kwon, S.Y., Lim Y.D. and Simnett, R. (2010). “Mandatory Audit Firm Rotation and Audit Quality: Evidence from Korean Audit Market", Working Paper, University of New South Wales, Australia .

Kwon, S.Y., Lim, Y., and Simnett, R. (2014). "The Effect of Mandatory Audit Firm Rotation on Audit Quality and Audit Fees: Emprical Evidence from the Korean Audit Market", Auditing: A Journal of Practise \& Theory, 26(1), 113-131.

Lennox, C. (2007). “Auditor Tenure and Rotation, Template: Royal a Font" Date: 10/06/2014; 3B2 version: 9.1.406/W Unicode (May 24 2007) (APS_OT),

Dir: //integrafs1/kcg/2agination/TandF/ROCA_RAPS/ApplicationFiles/9780415633635.3d. Date of access: $15 / 02 / 2017$.

Lennox, C.S., Wu, X. and Zhang, T. (2014). “Does Mandatory Rotation of Audit Partners Improve Audit Quality?", The Accounting Review American Accounting Association, 89(5), 1775-1803.

Mansi, S. A., Maxwell, W. F., and Miller, D. P. (2004). “Does Auditor Quality and Tenure Matter to Investors? Evidence from the Bond Market," Journal of Accounting Research, 42(4), 755-793.

Mautz, R.K and Sharaf, H.A. (1961). The Philosophy of Auditing. American Accounting Association, Monograph No 6, Sarasota Fl.

Mohrmann, U. (2017). "What are the Drivers of Audit Quality After an Auditor Change? Evidence from Voluntary and Mandatory Auditor Switches," (August 16, 2017). Available at, SSRN: https://ssrn.com/abstract=2589486 or http://dx.doi.org/10.2139/ssrn.2589486. Date of access: $18 / 04 / 2018$.

Moore, D., Tetlock, P., Tanlu L. and Bazerman, M. (2006). "Conflicts of Interest and the Case of Auditor Independence: Moral Seduction and Strategic Issue Cycling", Academy of Management Review, 31(1), 10-29.

Myers, J. N., Myers, L. A. and Omer, T. C. (2003). “Exploring the Term of the Auditor-Client Relationship and the Quality of Earnings: A Case for Mandatory Auditor Rotation", The Accounting Review, 78(3), 779- 799. 
Nagy, A. (2005). “Mandatory Audit Firm Turnover, Financial Reporting Quality and Client Bargaining Power: The Case of Arthur Anderson", Accounting Horizons, 19(2), 51-68.

Raiborn, C., Schorg, C.A. and Massoud, M. (2006). "Should Auditor Rotation be Mandatory?" The Journal of Corporate Accounting and Finance, 17(4), 37-49.

Yaşar, A. (2013). “Big Four Auditors' Audit Quality and Earnings Management: Evidence from Turkish Stock Market", International Journal of Business and Social Science, 4(17), 153-163. 